\title{
A Bronze Age Burial from Pabay Mor, Isle of Lewis, Western Isles
}

\author{
Rachel Barrowman and Lorna Innes \\ GUARD, Gregory Building, Lilybank Gardens, University of \\ Glasgow, Glasgow G12 8QQ \\ With contributions from \\ Paul Duffy, Gavin MacGregor and Beverley Ballin-Smith \\ Illustrations by John Arthur
}

Scottish Archaeological Internet Report 29, 2009 www.sair.org.uk 
Published by the Society of Antiquaries of Scotland, www.socantscot.org with Historic Scotland, www.historic-scotland.gov.uk and the Council for British Archaeology, www.britarch.ac.uk

Editor Helen Bleck

Produced by Archetype Information Technology Ltd, www.archetype-it.com ISBN: 9780903903981

ISSN: $1473-3803$

Requests for permission to reproduce material from a $S A I R$ report should be sent to the Director of the Society of Antiquaries of Scotland, as well as to the author, illustrator, photographer or other copyright holder.

Copyright in any of the Scottish Archaeological Internet Reports series (text and illustrations) rests with the SAIR Consortium and the individual authors.

The maps are reproduced from Ordnance Survey material with permission of Ordnance Survey on behalf of the Controller of Her Majesty's Stationery Office. (C) Crown copyright 2001. Any unauthorised reproduction infringes Crown copyright and may lead to prosecution or civil proceedings. Historic Scotland Licence No. GD03032G, 2002.

The consent does not extend to copying for general distribution, advertising or promotional purposes, the creation of new collective works or resale. 


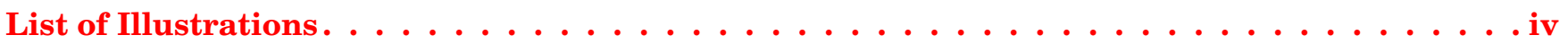

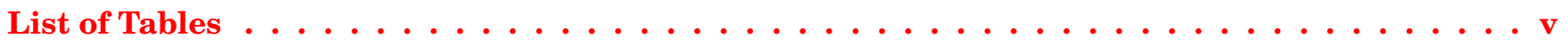

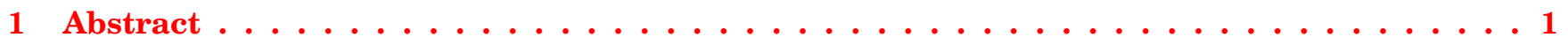

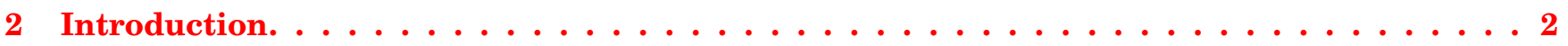

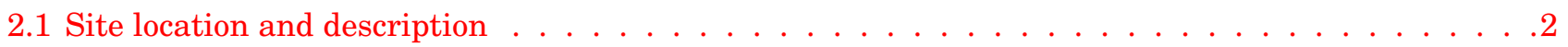

2.2 Circumstances of discovery and background to the excavation $\ldots \ldots \ldots \ldots \ldots \ldots$

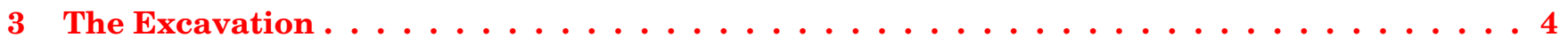

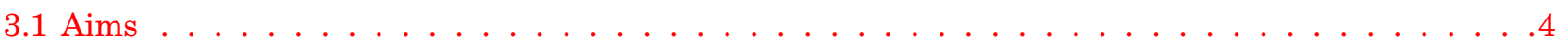

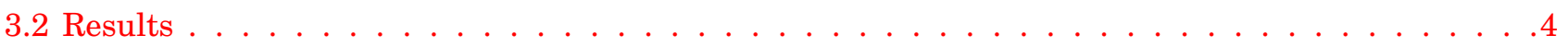

4 The Human Remains $($ Paul Duffy) $\ldots \ldots \ldots \ldots \ldots$

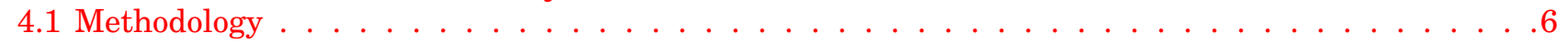

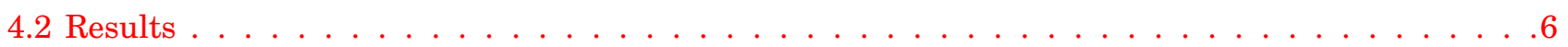

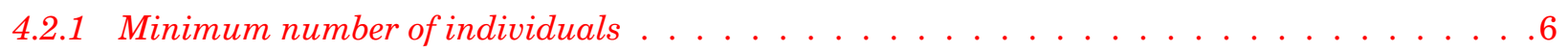

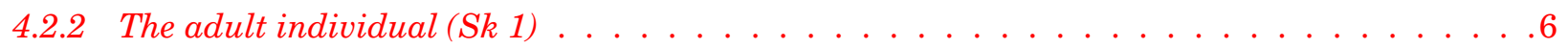

4.2.2.1 Biological age at death. . . . . . . . . . . . . . . . . . . .6

4.2 .2 .2 Biological sex. . . . . . . . . . . . . . . . . . . . . 6

4.2 .2 .3 Metric data. . . . . . . . . . . . . . . . . . . . .6

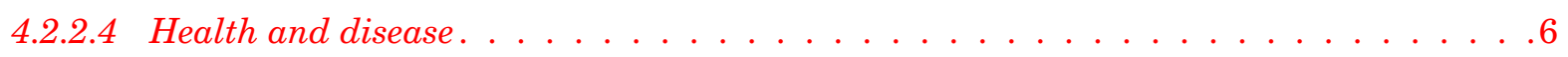

4.2 .3 The infant individual $(S k 2) \ldots \ldots \ldots \ldots \ldots \ldots \ldots \ldots$

5 The Radiocarbon Dates (Lorna Innes) $\ldots \ldots \ldots \ldots$

6 The Pottery (Gavin MacGregor) $\ldots \ldots \ldots \ldots \ldots \ldots \ldots$

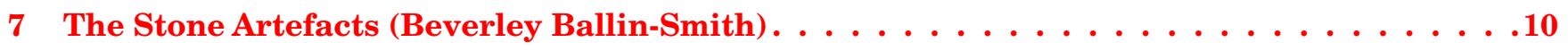

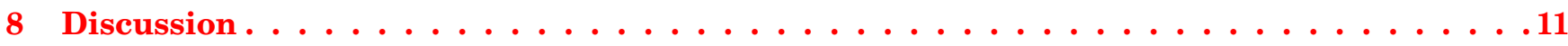

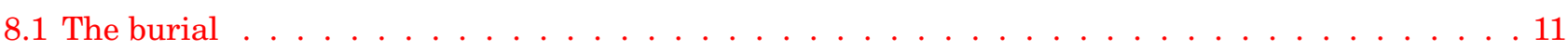

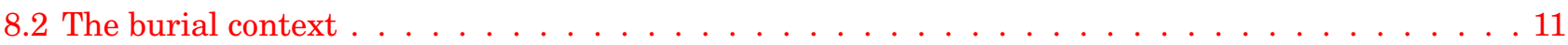

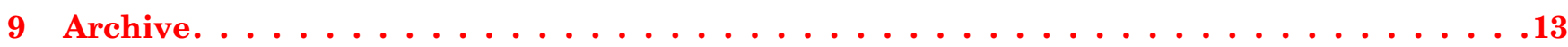

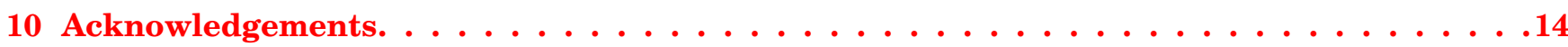

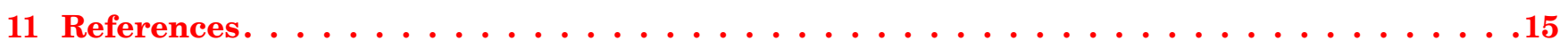




\section{LIST OF ILLUSTRATIONS}

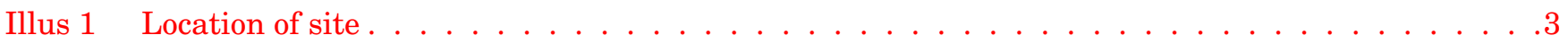

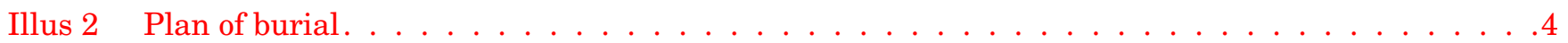

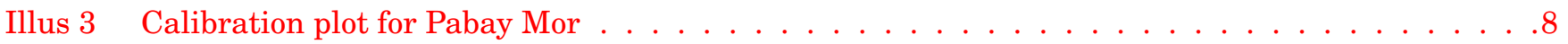

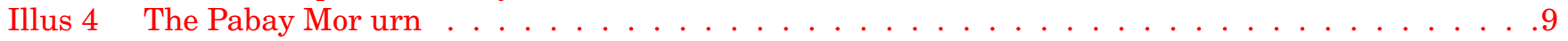




\section{LIST OF TABLES}

Table 1 Radiocarbon dates from Pabay Mor and comparative sites from Lewis . . . . . . . . . . . . . . . .8

Table 2 The characteristics of the stone assemblage . . . . . . . . . . . . . . . . . 10 


\section{ABSTRACT}

In 2002 human remains were reported eroding from a section of sandy cliff on the eastern side of the island of Pabay Mor, Isle of Lewis. Subsequent excavation of the site was undertaken by GUARD, as part of the Historic Scotland Human Remains Call-off Contract. This revealed a burial of a mature male of approximately 50-59 years of age, placed in a grave adjacent to a marker stone. The burial was crouched and aligned north-south and accompanied by a small undecorated pot, a polished stone and a pumice polisher. A radiocarbon date of 1450-1290 cal BC (GU-13838) was obtained from human bone from the burial. A second, infant, individual, represented only by a fragment of mandible, was identified from disarticulated remains found at the burial.

The project has been funded by Historic Scotland. 


\section{INTRODUCTION}

\subsection{Site location and description}

This report describes the discovery, excavation and identification of a crouched burial and group of disarticulated human remains recovered from the eroding sandy cliff on the east side of Pabay Mor, a small island off the west coast of Uig on the Isle of Lewis (illus 1). The burial was discovered at NB 10483795 at the north end of a sandy bay, Traigh na Cille, on the east side of the island. It lay towards the top of a large machair-covered mound of windblown sand that had accumulated at the top of the cliff. This sand had been eroding dramatically with each storm, to the extent that up to $1.5 \mathrm{~m}$ was lost in the winter of 2001.

\subsection{Circumstances of discovery and background to the excavation}

Human remains were first observed at the site by the landowner, Mr John Hobbs, who in 1998 recovered a selection of human bone, including two skulls, femurs, a clavicle and a scapula, amongst other bones, from the eroding cliff and the beach below. The remains were subsequently deposited in the Uig museum. In 2002 he observed further eroding remains at the top of the cliff and contacted the Western Isles Council archaeologist, Dr Mary MacLeod, who reported them to the local police. Dr MacLeod then visited the site on 14 August 2002 and noted that disarticulated remains were scattered within re-deposited sandy topsoil $c 2.7 \mathrm{~m}$ above the base of the sandy cliff, close to a marker stone. She also noted that the ground around the marker stone had been disturbed, and further investigation confirmed that some digging had occurred here previously and had resulted in the re-deposited soil and human remains.

The disarticulated and jumbled bones were carefully removed to reveal a dark soil which contained in situ human remains and a possible Bronze Age pot. Glasgow University Archaeological Research Division (GUARD) was then contacted by Historic Scotland and commissioned to excavate the remains under the provisions of the Human Remains Call-off Contract. On 16 August 2002 Rachel Barrowman attended the site on behalf of GUARD with Mark Elliot of the Museum nan Eilean. The site was found at the edge of an eroding sandy cliff, in a small rectangular de-turfed area of $c 0.65 \times 1 \mathrm{~m}$ to the east of the marker stone. The site was fully excavated and recorded, and the pottery and remains were taken to the museum in Stornoway. 


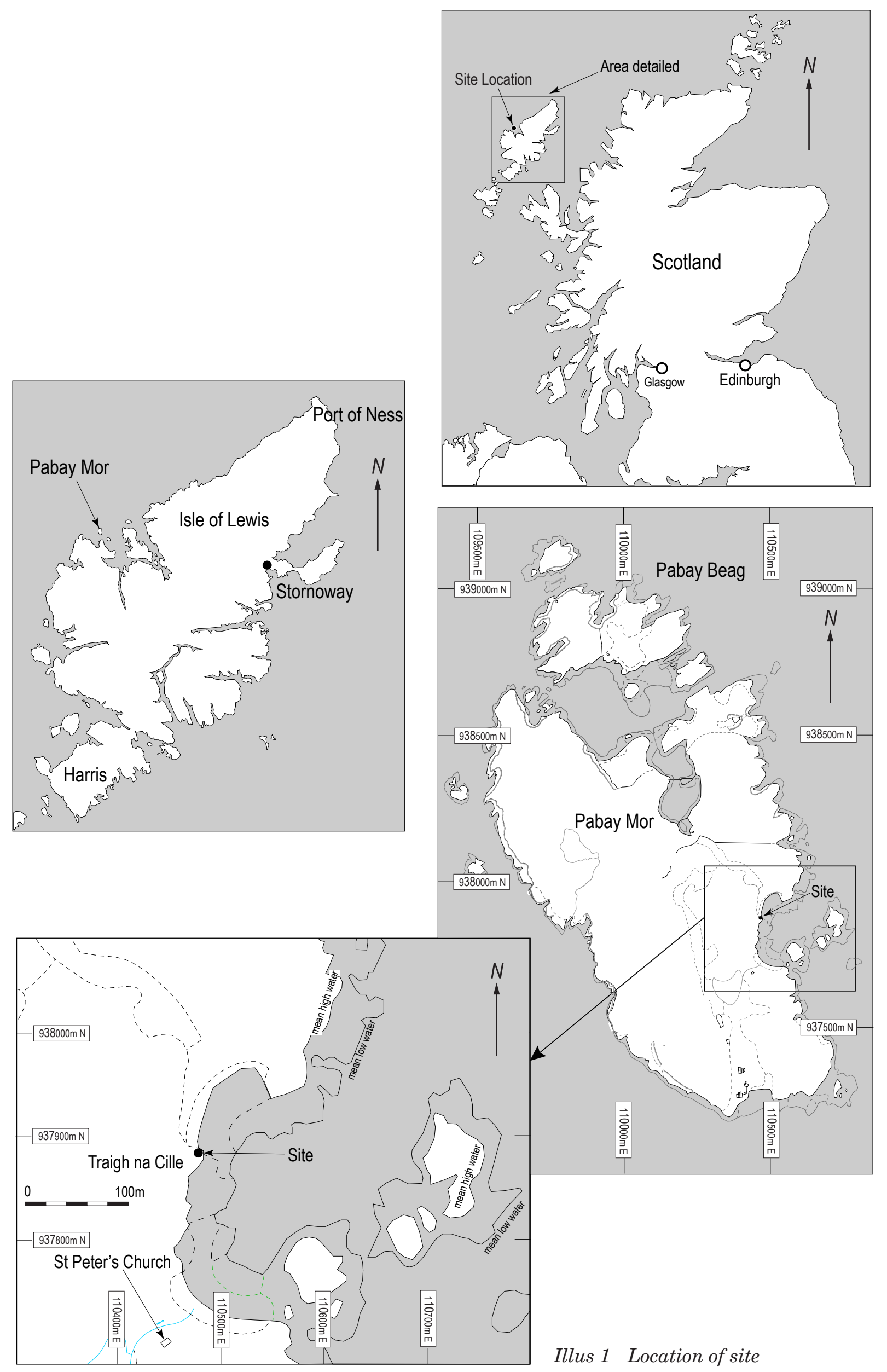




\section{THE EXCAVATION}

\subsection{Aims}

The aims of the excavation were to recover human remains and other archaeologically significant artefacts from the site, to mitigate against any further loss of information through erosion by the acquisition of a detailed archaeological record and to establish the date and character of the site within both its immediate environs and wider context.

\section{$3.2 \quad$ Results}

Three discrete areas of human remains were identified at first, but with further investigation it became clear that they represented a north-southaligned burial (Sk 1 = SF 12) which was somewhat disturbed and partially articulated. At the northern end of the trench a mandible was uncovered, adjacent and at right angles to articulated cervical and thoracic vertebrae (including the atlas and axis), a sternum and a fragment of scapula. Ribs, a clavicle and vertebrae were also recovered from this area although disarticulated from the other remains. A tibia with articulated patella overlay an articulated leg (tibia, fibula, patella and femur) in an extreme flexed position. At the south end of one femur, and corresponding with the end of the tibia, almost an entire articulated foot had survived intact, including the tarsal, metatarsal and most of
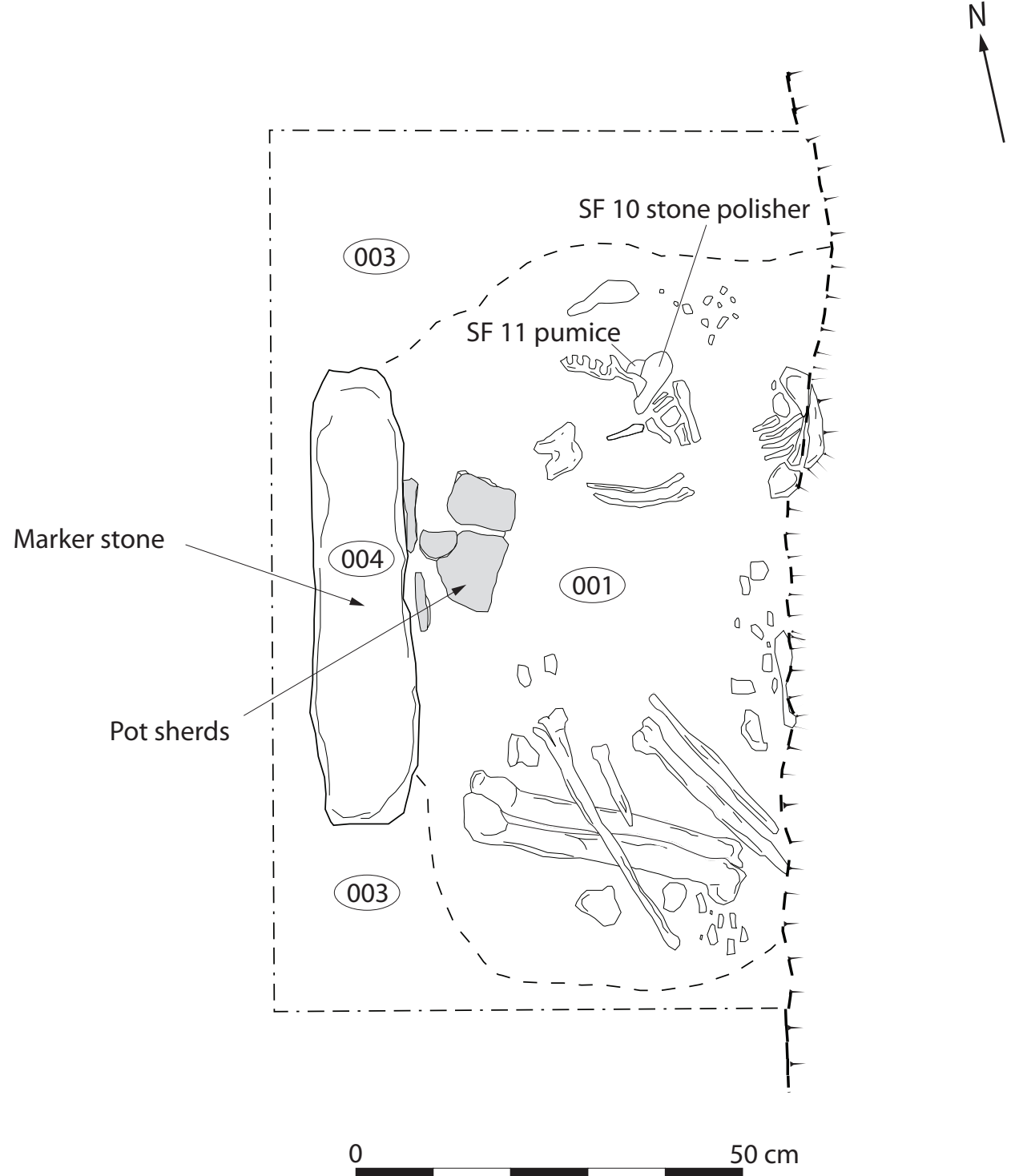
the phalanges. Hand bones (carpal bones, metacarpals and phalanges) were found scattered in an area between the two previously mentioned groups. At the east edge of the cliff face, a clavicle and several ribs were recovered in a damaged state and a vertebra was found lying adjacent to an ulna and radius with elbow articulation. No bones from the pelvis or the remainder of the skull were present.

A polished pebble (SF 10) and a smoothed, worked piece of pumice (SF 11) were recovered from the posterior of the mandible (see Ballin-Smith below). The ribs and vertebrae to the west of the mandible (see illus 2) were overlaid by a broken pot (SF 13) (illus 4) which was found lying on its side and broken into many pieces on the west side of the burial, adjacent to a large stone (Context 004). Water running down the stone had percolated through the pot, severely degrading the fabric in the process, especially on its lower side. However, the rim was noted to be in good overall condition and a large proportion of the pot was present (see MacGregor below).

The burial was situated in an area of dark brown to black, moderately firm silty sand (Context 001) with organic inclusions, up to $0.05 \mathrm{~m}$ thick, that was associated with Sk 1 and was seen as a stain within the windblown sand below. The layer formed a rectangular shape, aligned north-south around the burial, cut on the east side by the eroding cliff edge and defined to the west by a large marker stone
(Context 004) (illus 2). No trace of an associated cairn or cist was found.

The burial Sk 1 and dark layer (Context 001) were partially covered by a loose, light-greyish brown sandy topsoil (Context 002), up to $0.3 \mathrm{~m}$ thick, which contained several disarticulated human bones including fragments of scapula, a humerus, a femur, vertebrae, fragments of broken pelvis and other fragments. Some of the bones were stained darker, suggesting that they had been dug out from the burial in Context 001 below and then redeposited into the topsoil above. It is very likely that these remains had been disturbed by whoever had excavated around the marker stone, as they had been returned to the ground in the same location but in a random fashion and re-covered with topsoil.

Prior to excavation the condition of the site was recorded by photographic and written record. The dimensions of the marker stone were recorded $(0.58 \mathrm{~m}$ long by $0.14 \mathrm{~m}$ wide and protruding $0.30 \mathrm{~m}$ from the turf) and the area around the stone was examined. As Dr MacLeod had previously noted, the area immediately around the marker stone had clearly been disturbed (ie dug into) at some time. The turf where it remained to the north, south and west of the stone was thinner than the surrounding area, and had sunk $0.2 \mathrm{~m}$ below the height of the adjacent ground surface, suggesting it had been recently cut and then redeposited. 


\section{THE HUMAN REMAINS by Paul Duffy}

\subsection{Methodology}

Three separate assemblages were presented for analysis: in situ material recovered from the excavation of Context 001 (Sk 1 = SF 12), disarticulated material recovered from the excavation of the topsoil 002 (SF 1-SF 8) and disarticulated material recovered prior to excavation by Dr MacLeod. It was thought likely by the excavator that all the skeletal material belonged to the same individual, as missing elements from the in situ remains were all observed in the assemblages of disarticulated remains recovered from the disturbed topsoil above. This hypothesis was borne out through observations during analysis.

Overall methodology was applied with reference to the current IFA/BABAO standards outlined in Brickley and McKinley (2004). This report summarises the analysis of the skeletal remains recovered during the project; full osteological data and observations have been deposited as part of the site archive.

\subsection{Results}

\subsubsection{Minimum number of individuals}

A minimum of two individuals were identified from the assemblage; one adult (Sk 1) and one infant (Sk 2 ). It is likely, given the consistency of bone morphology and lack of repeated elements, that the in situ adult material (Sk 1) and disarticulated adult material are from the same individual. The infant was represented by a single fragment of mandible, which was recovered from disarticulated material.

\subsubsection{The adult individual (Sk 1)}

\subsubsection{Biological age at death}

Skeletal maturity was found to be complete (28 years or older) for Skeleton 1. Third molars were present, indicating full dental maturation (18 or older) and the teeth were well worn, suggesting an age of 45 years or older. Examination of the auricular surface of the pelvis indicated a degree of wear consistent with an individual of between 50 and 59 years. An age of between 50 and 59 years at death (mature adult) is therefore suggested for the adult individual (Sk 1) based on these observations.

\subsubsection{Biological sex}

The morphology of the pelvic sciatic notch and overall appearance of the mandible suggested that the adult individual was male. Metric measurements of the glenoid fossa of the scapula supported the identification, although femoral head measurements were inconclusive. Overall morphological characteristics of the skeletal material further supported the assignment of sex as male.

\subsubsection{Metric data}

Stature was calculated as $163-169 \mathrm{~cm}\left(5^{\prime} 4^{\prime \prime}-5^{\prime} 6^{\prime \prime}\right)$, based on measurement of the right femur and tibia.

Platymeric indices calculated for the femur shape indicate a degree of difference between the legs (83 for right, 92 for left). This may support the observation of increased loading of the right-hand side of the body. A platycnemic index for the right tibia was also calculated at 76 , indicating that the tibia was broadly rounded (eurycnemic). Several reasons for such variations in the lower limb have been put forward, including mechanical stress and mineral and vitamin deficiency, but at present the utility of these observations is still open to debate (Waldron 2007, 47).

\subsubsection{Health and disease}

Overall the adult showed well-developed muscle markings throughout his skeleton, with the right side showing particular muscle development, potentially indicating right-handedness. An enthesopathy was also noted at the insertion of tibialis anterious on the left tibia, although the complex aetiology of such osseous changes precludes any assignment of causal factors. Overall these observations indicate that he pursued a vigorous lifestyle and was probably well muscled.

Evidence of spinal joint disease was also noted, almost exclusively confined to the cervical portion of the spinal column. Here, osteophyte formation and porosity of vertebral bodies was noted on $\mathrm{C} 2-\mathrm{C} 7$, and $\mathrm{T} 1$, with very erosive lesions noted on the bodies of $\mathrm{C} 2$, $\mathrm{C} 3, \mathrm{C} 5$ and $\mathrm{C} 7$. This process had also led to the fusion of $\mathrm{C} 5$ and $\mathrm{C} 6$ at the posterior aspect of the vertebral bodies. Indications of degeneration of the bone matrix were absent and the condition is therefore probably best diagnosed as osteophytosis with associated osseous ankylosis of C5 and C6 attributed to degeneration of the intervertebral discs. The relatively advanced stage of this condition further reinforces the picture of a vigorous lifestyle and repeated spinal column stress, potentially through heavy lifting and carrying of heavy objects on the back.

Dental health was found to be good, although the mandibular teeth were highly worn. Calculus was slight where it existed, and there was a complete absence of evidence of periodontal disease, caries 
or abscess formation. One tooth (right incisor 2) was found to be missing ante-mortem, although the reasons for this are unclear. The neighbouring canine was, however, rotated medially through 90 degrees, possibly a genetic trait of the individual.

Despite his age, no evidence of osteoarthritis was observed on any of the articular surfaces of the adult. This may further strengthen the suggestion that the observed spinal joint disease has a more specific cause than advanced age or a general vigorous lifestyle alone, as osteoarthritic changes may also have reasonably been expected if general age and lifestyle were the causes.

\subsubsection{The infant individual (Sk 2)}

No diagnostic indicators of age at death, biological sex or evidence of health and disease were identified from the single fragment of non-adult bone (Sk 2). The size of the element does, however, suggest that the individual falls into the wider age category of infant. 


\section{THE RADIOCARBON DATES by Lorna Innes}

A sample of bone from the adult individual ( $\mathrm{Sk}$ 1) only was submitted for radiocarbon dating as the remains of the infant (Sk 2) were considered too badly preserved and too small to be suitable. The radiocarbon date obtained places the adult burial in the mid to later second millennium $\mathrm{BC}$, and therefore within the Mid Bronze Age (illus 3). It locates the burial in a small group of Bronze Age burials that have been excavated and dated from Uig (see Table 1 and discussion below in 8.2).

Table 1 Radiocarbon dates from Pabay Mor and comparative sites from Lewis

\begin{tabular}{lllllll}
\hline Site & Lab code & $\begin{array}{l}\text { Sample } \\
\text { material }\end{array}$ & Yrs BP & $\delta^{\mathbf{1 3} C \% o}$ & $\begin{array}{l}\text { Calibrated date Calibrated date } \\
\text { at 1-sigma }\end{array}$ \\
\hline Pabay Mor & $\begin{array}{l}\text { SUERC-9172 } \\
\text { (GU-13838) }\end{array}$ & $\begin{array}{l}\text { Skeleton: left } \\
\text { talus (009) }\end{array}$ & $3105+35$ & -18.7 & $1430 \mathrm{BC}-1310 \mathrm{BC}$ & $1450 \mathrm{BC}-1290 \mathrm{BC}$ \\
& GU-1174 & $\begin{array}{l}\text { Burnt residue } \\
\text { from urn }\end{array}$ & $3410+55$ & -26.5 & $1860-1620 \mathrm{BC}$ & $1890-1530 \mathrm{BC}$ \\
$\begin{array}{l}\text { Cnip } \\
\text { (Close-Brooks 1995) }\end{array}$ & GU-3488 & $\begin{array}{l}\text { Skeleton: left } \\
\text { femur and tibia }\end{array}$ & $3360+50$ & (no info) & 1737-1613 BC & $1856-1520 \mathrm{BC}$ \\
$\begin{array}{l}\text { Cnip } \\
\text { (Dunwell et al 1995) }\end{array}$ & & & & & & \\
\hline
\end{tabular}

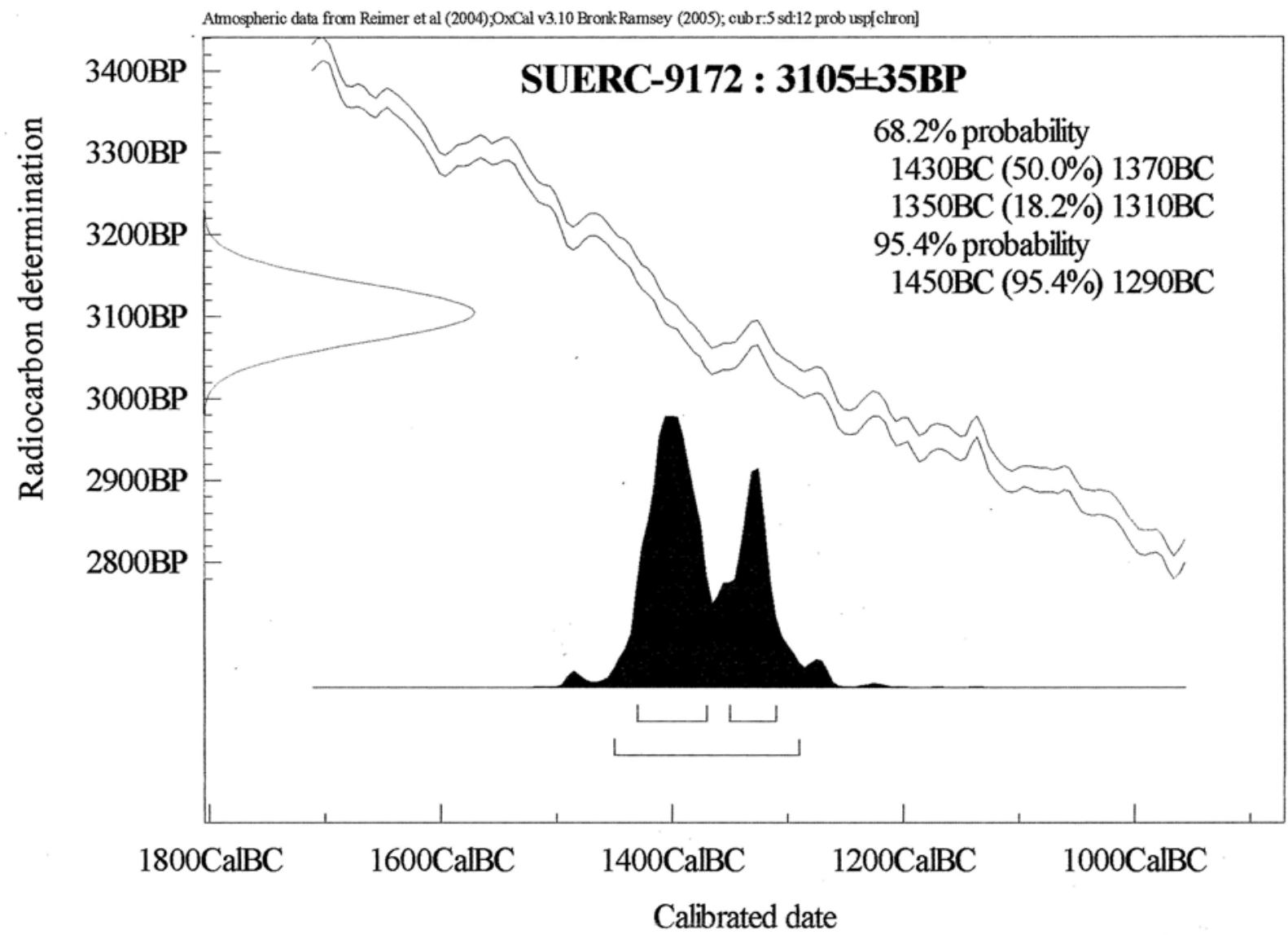

Illus 3 Calibration plot for Pabay Mor 


\section{THE POTTERY by Gavin MacGregor}

Pot sherds found to the immediate east of the marker stone (illus 2) derived from one vessel (SF 13; illus 4): a small, undecorated flat-based vessel with a pronounced foot and slight barrel-shaped profile. The rim is flat apart from a short portion where it has an external bevel; potentially where the rim has not been as carefully executed. A slight groove runs below the rim, probably created by running a finger around the vessel when wet.

The fabric is coarse with moderate angular stone temper, including quartz and a black igneous rock, up to $5 \mathrm{~mm}$ in length. The outer surface has been smoothed. The vessel originally had an orange-buff exterior and a grey-brown interior, suggesting the vessel was fired inverted. The outer surface is largely obscured with sooting, which is more pronounced on the upper body.

About three quarters of the vessel was recovered by the excavation, the rest presumably removed during the disturbance into the burial, as evidenced during the excavation of the topsoil above. The portions of the vessel that were located underneath, when it lay on its side, are very eroded, with the outer faces missing, probably due to water percolation. The vessel can be reconstructed to a height of $c 110 \mathrm{~mm}$.

The closest parallel found for the Pabay Mor vessel is the small, undecorated bipartite urn which was deposited in a cist at Cnip, Lewis, associated with human remains dated to 1856-1520 BC (GU-3488) (see Table 1; Dunwell et al 1995). There are affinities with the small undecorated urn deposited in a cist at Allasdale, Barra, associated with human remains dated to 1760-1600 BC (GU-14151) (Cook forthcoming). Also of note is the small, flat-based bucket-shaped urn from a cist at Port na Long, North Uist (Megaw \& Simpson 1961).

\section{Catalogue}

SF 13: 13 rim sherds, 8 basal sherds and 53 body sherds, fragments and crumbs.

Th $13 \mathrm{~mm}$ (body); Th $10 \mathrm{~mm}$ (rim); Rim diameter $150 \mathrm{~mm}$; Basal diameter $100 \mathrm{~mm}$; Wt $700 \mathrm{~g}$.

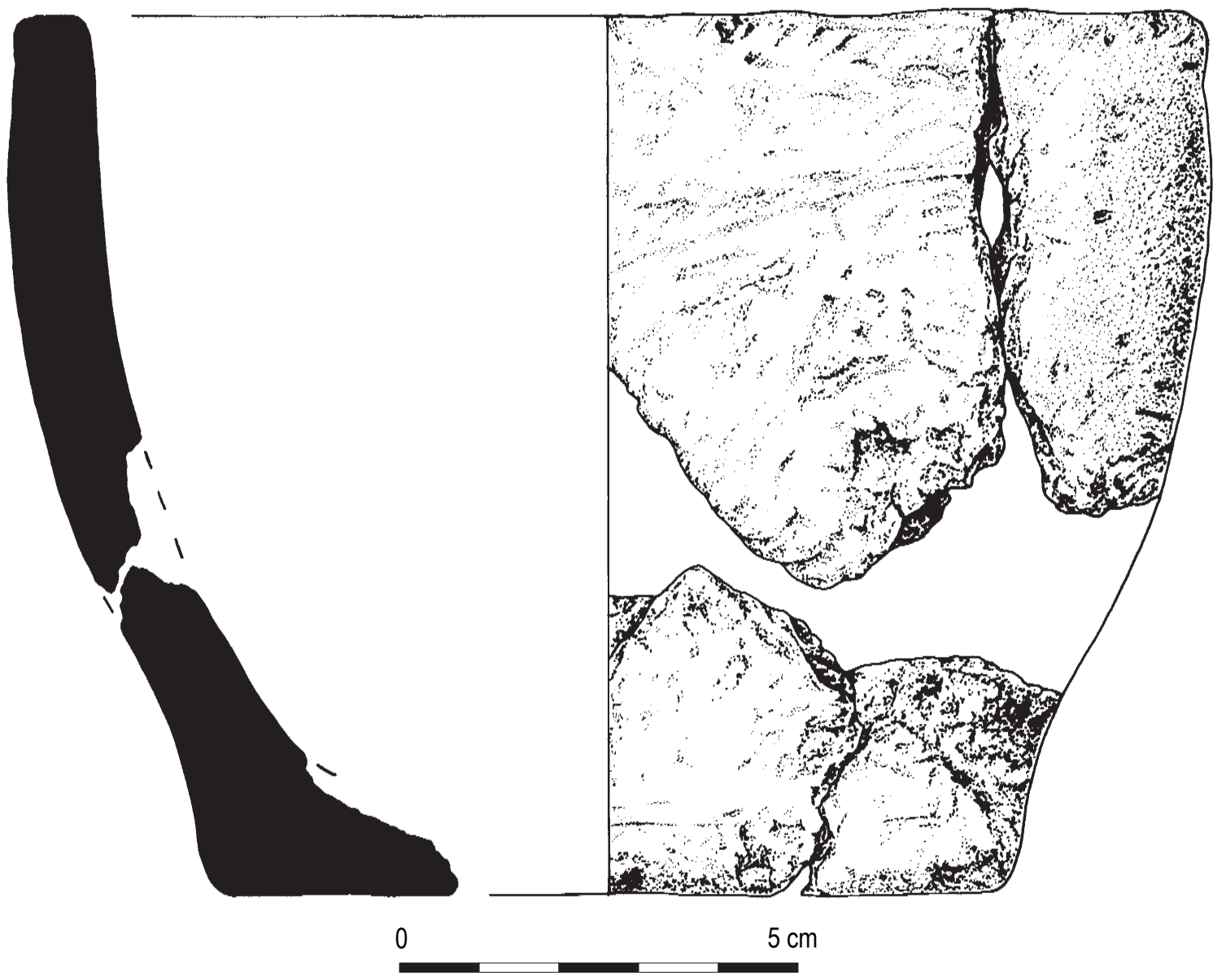

Illus 4 The Pabay Mor urn 


\section{THE STONE ARTEFACTS by Beverley Ballin-Smith}

Two stones, SF 10 and SF 11, were found close together with the burial, beside the mandible. The identification of the stones, their measurements (maximum dimensions) and their weight are recorded in Table 2 below.

$\mathrm{SF} 10$ is a smooth, rounded pebble whose lower surface is convex, with a central area of dark polish measuring approximately $30 \times 35 \mathrm{~mm}$. The stone is otherwise unaltered but it has calcareous adhesions on its upper surface. It is likely to have functioned as a polisher or burnisher, the polish being a result of the stone being used in a circular motion. Pebble polishers are typically found on Iron Age sites, but this does not preclude their use during other periods in prehistory (Ballin-Smith 1994, 196-201).

SF 11 is an irregularly shaped pebble of dark grey, vesicular pumice. One surface is smoothed and slightly concave, indicating that it has been used as an implement. The stone is otherwise unaltered. Pumice is commonly found on prehistoric coastal sites where it has been washed up on beaches. Pumice pebbles were often utilised as polishing tools (ibid, 212-13).

Table 2 The characteristics of the stone assemblage

\begin{tabular}{llllll}
\hline SF No. & Context & Material & Measurements & Weight & Comments \\
\hline 10 & 001 & Quartzite & $66 \times 55 \times 31 \mathrm{~mm}$ & $194.7 \mathrm{~g}$ & Has an area of polish \\
11 & 001 & Pumice & $61 \times 34 \times 28 \mathrm{~mm}$ & $19.5 \mathrm{~g}$ & Possibly worked \\
\hline
\end{tabular}




\section{Discussion}

\subsection{The burial}

The Pabay Mor flexed inhumation of a mature male (50-59 years), aligned roughly north-south, was buried in the Mid Bronze Age (1450-1290 cal BC) into a grave, as reflected by a rectangular-shaped area of dark brown to black silty sand (Context 001). A large stone had been set at the western edge of the burial, perhaps as a marker, and a small, plain barrel-shaped pot was placed directly next to the marker stone, although it is unclear whether it was smashed during or post-deposition. A polished stone and pumice polisher found adjacent to the mandible and upper spine of the body may also have been deposited at the time of burial.

The grave did not appear to be related to the remains of a burial mound or cist structure, although it is not impossible that the marker stone once formed part of a larger mortuary feature, which has since eroded from the cliff.

The burial had been recently disturbed, and was only partially articulated, with the lower limbs being better preserved than the upper body. It was covered by re-deposited sandy topsoil (Context 002), which contained disarticulated human remains. A fragment of an infant mandible was recovered from the disarticulated remains above the burial and suggests the presence of a second individual nearby. Human remains, including two skulls, found by the landowner from the eroding cliff line and beach in the vicinity of the site in 1998 suggest that there were once further burials present at the site, possibly associated with the Pabay Mor inhumation.

\subsection{The burial context}

The burial at Pabay Mor adds to growing knowledge of Bronze Age burial archaeology from the Western Isles. Bronze Age burials have been recorded from the islands (eg Megaw \& Simpson 1961) but until recently detailed information was often scant and dating evidence imprecise. Recent work on Lewis, and further south in South Uist and Barra (Branigan and Foster 2000, 192-215; Close-Brooks 1995; Dunwell et al 1995; Neighbour 2005; Parker Pearson et al 2005; Parker Pearson et al 2007; Cook forthcoming), has begun to change this.

The use of contemporary inhumation and cremation practices is a feature of the Bronze Age and is evidenced, perhaps significantly, at Cnip on the Bhaltos peninsula, which overlooks Pabay Mor (Armit 1994, 74-5) and is the closest dated comparison to the Pabay Mor burial. The Cnip Bronze Age cist inhumation was excavated in 1992 (Dunwell et al 1995), and lay only $5 \mathrm{~m}$ from a previously excavated cairn from the same period (Close-Brooks 1995). The remains within the cist were of a mature male (35-40 years) orientated roughly east-west and in a flexed position. A coarse plain vessel (almost intact) was positioned adjacent to the head and was the only artefact recovered from the grave (Dunwell et al 1995, 279). The radiocarbon date (1856-1520 $\mathrm{BC})$ establishes this inhumation to be earlier than the Pabay Mor burial (1450-1290 BC) but potentially contemporary with the inverted urn cremation found within the Cnip cairn (1890-1530 BC (GU1174)). Further south in the Western Isles examples of both inhumation and cremation within separate short cists below a mound were found at Sithean an Altair in Vallay (Megaw \& Simpson 1961, 76). In the Bronze Age, inhumation was clearly not replaced by cremation but was a practice that continued in tandem with it, and the Mid Bronze Age Pabay Mor inhumation fits well with this picture.

The reason for the presence of the infant jaw bone in the Pabay Mor burial is unclear. It is possible that it represents all that remains of a child buried with the adult, although this cannot be confirmed as the infant bone was found amongst disarticulated material recovered from the disturbed soil above the burial. It is known that further human remains were also recovered from the beach below the grave in 1998, but whether they originated from this grave or another is also unfortunately now unknown. The presence of more than one individual in a cist is a feature of many Bronze Age burials. At the south end of the Western Isles chain, at Allasdale, Barra, four cists, containing the inhumed remains of 13 individuals, were recently excavated and dated to $1880-1490$ BC (GU-14153 \& GU-14152) (Cook, forthcoming). Although the dates are earlier than at Pabay Mor, the presence of more than one individual in three of the cists and of children, adults and both sexes, is striking and may have similarities with the Pabay site.

The most obvious difference between the burial at Pabay Mor and other Bronze Age burials excavated in the Western Isles is the lack of cist structure associated with the Pabay Mor inhumation. At Cnip, the cist inhumation may have been covered with a mound, as suggested by the presence of the partial remains of a likely kerb to the south of the feature (Dunwell et al 1995, 282). The Pabay Mor burial was in contrast essentially a grave with a marker stone, although it is possible that further stones associated with the burial were already lost to the sea prior to the excavations, or that kerb stones may have been present below the sand in the area outwith the excavation trench. 
The Pabay Mor adult male is also broadly contemporary with recently excavated evidence for human remains in a domestic context, found from below the floors of houses at the late Bronze Age and early Iron Age settlement at Cladh Hallan on South Uist. Homes here were built over foundation pits containing composite burials of articulated remains, apparently deposited several hundred years after their death, which may have been subject to mummification (Parker Pearson et al 2005; 2007). Over the years at Allasdale several artefacts, including hammer stones, bone tools and pottery, have also been recovered from the immediate vicinity of the burials, implying that there was once domestic settlement in close proximity to the graves. However, at Allasdale, as at Pabay Mor and Cnip, plain pots were also found within the burials, and the recovery of the polished stone and pumice polisher from Pabay Mor, is more suggestive of deliberate inclusions placed with the burial, rather than nearby domestic settlement. But without further detailed investigation, or possibly monitoring of the erosion, the presence of a nearby domestic settlement cannot be ruled out.

The remains recovered from the burial on Pabay Mor add to our overall knowledge of burial practices in the Western Isles, where, as elsewhere, a 'mixture of striking similarities and unfathomable differences is a feature of Bronze Age burial rites' (Neighbour 2005, 61). The Pabay Mor Mid Bronze Age adult male inhumation was marked with a large stone and buried with a pot, polished stone and pumice polisher, and possibly at least one accompanying individual as represented by an infant jaw bone and other disarticulated material recovered from the area prior to the excavation. The excavation and analysis of this burial, whilst small in scale, contributes to a growing body of evidence relating to mortuary and funerary practices in the Western Isles during the second millennium BC. 


\section{$9 \quad$ ARCHIVE}

The full project archive will be deposited with the National Monuments Record of Scotland. Finds disposal will be conducted through the Treasure Trove procedures. 


\section{ACKNOWLEDGEMENTS}

The project was funded by Historic Scotland as part of the Human Remains Call-off Contract. The authors would like to thank Mr Mark Elliot (Museum nan Eilean), Mr John Hobbs, Dr Mary MacLeod (Western Isles archaeologist) and John Atkinson (GUARD).
Thanks also go to Jen Cochrane and Laura Hayes for their administrative assistance. Dave Swan and John Arthur produced the plan illustrations and Jill Sievewright the pottery illustration. 


\section{REFERENCES}

Armit, I 1994 'Archaeological field survey of the Bhaltos (Valtos) peninsula, Lewis', Proc Soc Antiq Scot 124, 67-93.

Ballin-Smith, B (ed) 1994 Howe: Four Millennia of Orkney Prehistory. Society of Antiquaries of Scotland, Monograph Series, No. 9, Edinburgh.

Brannigan, K \& Foster, P (eds) 2000 From Barra to Berneray: Archaeological Survey and Excavation in the Southern Isles of the Outer Hebrides. Sheffield Academic Press, Sheffield.

Brickley, M \& McKinley, J 2004 Institute of Field Archaeologists Technical Paper No 7: Guidelines to the Standards for Recording Human Remains. Institute of Field Archaeologists/ British Association for Biological Anthropology and Osteoarchaeology, Reading.

Close-Brooks, J 1995 'Excavation of a cairn at Cnip, Uig, Isle of Lewis', Proc Soc Antiq Scot 125, 253-77.

Cook, M forthcoming "The excavation of a middle Bronze Age cemetery, Allasdale, Barra, Western Isles', SAIR, Edinburgh.

Dunwell, A J, Neighbour, T \& Cowie, T G 1995 'A cist burial adjacent to the Bronze Age cairn at Cnip, Uig, Isle of Lewis', Proc Soc Antiq Scot 125, 279-88.
Megaw, J V S \& Simpson, D D A 1961 'A short cist burial on North Uist and some notes on the prehistory of the Outer Isles in the second millennium BC', Proc Soc Antiq Scot 94 (1961-62), 62-79.

Neighbour, T 2005 'Excavation of a Bronze Age kerbed cairn at Olcote, Breasclete, near Calanais, Isle of Lewis', SAIR 13, Edinburgh.

Parker Pearson, M; Chamberlain, A; Craig, O; Marshall, P; Mulville, J; Smith, H; Chenery, C; Collins, M; Cook, G; Craig, G; Evans, J; Hiller, J; Mongomery, J; Schwenniger, J-L; Taylor, G \& Wess, T 2005 'Evidence for mummification in Bronze Age Britain', Antiquity 79, 529-46.

Parker Pearson, M; Chamberlain, A; Collins, M; Cox, C; Craig, G; Craig, O; Hiller, J; Marshall, P; Mulville, J \& Smith, H 2007 'Further evidence for mummification in Bronze Age Britain', Antiquity 81, (www.antiquity.ac.uk/ProjGall/ parker/index.html).

Waldron, T 2007 St Peter's, Barton-upon-Humber, Lincolnshire: A Parish Church and its Community Vol. 2: The Human Remains. Oxbow Books, Oxford. 